\title{
DETERMINATION OF SUSTAINABLE BUSINESS FACTORS OF ISLAMIC BANKS IN INDONESIA
}

\author{
Indra Siswanti and Y. Ferry Cahaya
}

Faculty of Economic and Business, Perbanas Institute

\begin{abstract}
The objective of the study is to examine the effect of corporate intellectual capital and company size on sustainable business through financial performance as a mediating variable. The data used is secondary data of financial and annual reports for 2010-2018 period. The population of this study is 9 (nine) Islamic Banks, and the samples used are saturated sampling, thus the sample used is all the 9 (nine) Islamic Banks. The data processing method used is Partial Least Square (PLS). The results of the study finds that intellectual capital has a significant effect on financial performance, company size has a significant effect on financial performance, where as intellectual capital has no effect on sustainable business. The study also finds that financial performance has a significant effect on sustainable business. Financial performance has a full mediating influence of intellectual capital on sustainable business, and financial performance has a partial mediating influence of company size on sustainable business.
\end{abstract}

Keywords: Intellectual Capital, Company size, Financial Performance, and Sustainable Business

\section{INTRODUCTION}

The development of Islamic banks in Indonesia according to the Financial Services Authority (Indonesian, OJK) 2018 has been documented as for 13 Islamic Banks, 22 Islamic Business Units, 165 Islamic rural banks. The development of Islamic banks in Indonesia is considered significant, this is because the implementation of the Islamic banking laws have contributed to the growth of Islamic banks in Indonesia. The existence

Vol. 27, No. 2 August 2019 
of Islamic banks in Indonesia has been around for a long time, about 25 years ago. The greater the growth of Islamic banks in Indonesia, the more people are going to be serving. The more widespread the reach of Islamic banks, it shows the role of Islamic banks is increasingly substantial in serving the people of Indonesia.

Market share of Islamic banks in Indonesia in 2018 has reached $5.72 \%$. Islamic banks experienced a fairly high growth of $15.2 \%$ or much higher than the growth of national conventional bank which reached $8.4 \%$. This means that Islamic banks have managed to escape the $5 \%$ traps. Looking at the growth of Islamic commercial banks in Indonesia that has always improved, it is vital to review important factors in support of the sustainability of Islamic banks in Indonesia. These factors include intellectual capital, company size and financial performance.

Bollen et al. (2005) argued that intellectual capital is as an integral part of the company in the process of value creation, and increasingly plays an important role in maintaining the company's competitive advantage. In the modern business environment, intellectual capital is regarded as the most important strategic asset to company success (Rezaei, 2014). As revealed by Chen, et al. (2005), intellectual capital has a significant effect on financial performance (Siswanti, et al, 2017). Similarly, Ulum et al. (2008) states that intellectual capital has a significant effect on the financial performance. Interestingly, Carrington (2012); Fathi et al. (2013); Nawaz et al. (2014) have the same findings where intellectual capital has a significant effect on the financial performance.

In consideration of investment decision making, investors often look at company size and evaluate financial performance. The company size is an estimating variable that is widely used to explain variations in social disclosures in annual reports made by the company. This is related to agency theory that predicts large companies that have higher agency costs, revealing greater information in order to reduce the high agency costs, and larger companies tend to have higher public demand for information than smaller companies (Sembiring, 2005). This is in accordance with research by Firmansyah dan Suwitho (2017), Alex and Ngaba (2018), states that the company size as measured by total assets has a significant effect on financial performance of manufacturing companies listed on the Indonesia Stock Exchange. 
Profitability is one measure for investors to invest, because profitability is a measure used to determine the company's ability to generate profits. Profitability can be used as a means to convey information to investors. Dilling (2009) states that companies with high characteristics of profitability and strong long-term growth will affect on sustainability business. This is in accordance with the research conducted by Maskun (2013), which shows that leverage levels, company size and profitability have a significant and positive impact on disclosure of CSR, which in turn increases the welfare of the community.

Sustainability is a balance between people-planet-profit, known as the triple bottom line (TBL) concept. Sustainability lies in the meeting between three aspects, peoplesocial; planet-environment; and profit-economy (Elkington, 1998). Often companies focus only on increasing profits and using technology as efficiently as possible so that sometimes disregards environmental and social aspects. Along with these conditions, the awareness of the Indonesian people about the importance of the company's environmental and social performance began to grow. This awareness encourages people to want disclosure of information by companies that are not only focused on one aspect of performance, but overall indicators of sustainability performance, economic, social and environmental performance. Companies that ignore social norms will lose goodwill from consumers, workers and regulators (Bary and Bouma, 2009).

Based on the results of the previous discussions, the study aims to firstly examine the effect of intellectual capital on financial performance, secondly to examine the effect of company size on financial performance, thirdly to examine the effect of intellectual capital on business sustainability, fourthly to examine the effect of company size on business sustainability, fifthly to examine effect of financial performance on business sustainability, sixthly to examine intellectual capital on business sustainability mediated financial performance and seventhly to examine company size on business sustainability mediated financial performance.

The study is expected to contribute to the development of financial management sciences, especially the financial management of the Islamic banks, and the application of intellectual capital related to the financial and sustainable business performance of the Islamic banks. In addition, the study is expected to be able to build intellectual capital as part of financial statements. This provides benefits for the Islamic banks to manage their

Vol. 27, No. 2 August 2019 
intellectual capital and assets for better. This is also in preparation to enter in the global market competition and in competitive advantage for the Islamic banks.

\section{LITERATURE REVIEW}

\section{Intellectual Capital}

Intellectual capital is an intangible asset owned by an Islamic banks and is used by Islamic banks to generate benefits and improve welfare through value added. In this research the intellectual capital variable is measured by three indicators: human capital (HC), structural capital (HC) and capital employed (CE). The stages of measuring intellectual capital according to Ulum (2013) are as follows:

1. Calculating iB-Value Added (VA) with the following formula"

$$
\text { iB-VA = OUT - IN }
$$

2. Calculating $i B$-Value Added Capital Employed (iB-VACA) with the formula:

$$
\text { iB-VACA = VA/CE }
$$

3. Calculating $i B$-value added human capital (iB-VAHU), with the formula:

$$
\text { iB-VAHU = VA/HC }
$$

4. Calculating Structural Capital Value Added (iB-STVA), with the formula:

$$
\text { iB-STVA = SC/VA }
$$

\section{Company size}

The company size is the measure of a standard company. The indicator used in this study to measure the level of company size is the total assets of the company (Siswanti, et al, 2017). Company size can be formulated as follows:

$$
\text { Size }=\ln (\text { total assets) }
$$

\section{Financial Performance}

According to Asmirantho (2013) the notion of financial performance is the determination of certain measures that can measure the success of an organization or company in generating profits. Whereas according to IAI (2007) Financial Performance is the company's ability to manage and control the resources it has. In this study financial performance is measured by the level of profitability reflected by Return on Assets (ROA) which is calculated by the following formula: 


$$
\text { ROA }=\text { net profit before tax } \times 100 \%
$$

Total Assets

\section{Sustainable Business}

Sustainable business in this research was measured by 3 aspects namely economic aspects, consits of 6 items, social aspects consits of 10 items and environmental aspects consits of 8 items of questions with reference to the Global Reporting Initiative (GRI) 2013 G4. To get an objective value in measuring sustainable business, an index analysis of scores that is calculated by self-assessment using question items is used, so each Islamic banks can assess the condition of the sustainability of its business.

Furthermore, each item question that is disclosed will be given a value: $3 ; 2$ or 1 . Value 3 will be given if the question item is fully disclosed and disclosed in detail in the annual report, value 2 will be given if the item question is only disclosed in the annual report without any detailed explanation and value 1 is given if the question item not disclosed in the annual report. Then the values are summed according to each indicator.

\section{Theoretical Framework and Hypothesis}

From the research framework, it can be seen that there is an effect between independent variables on the dependent variable, and financial performance as an intervening variable.

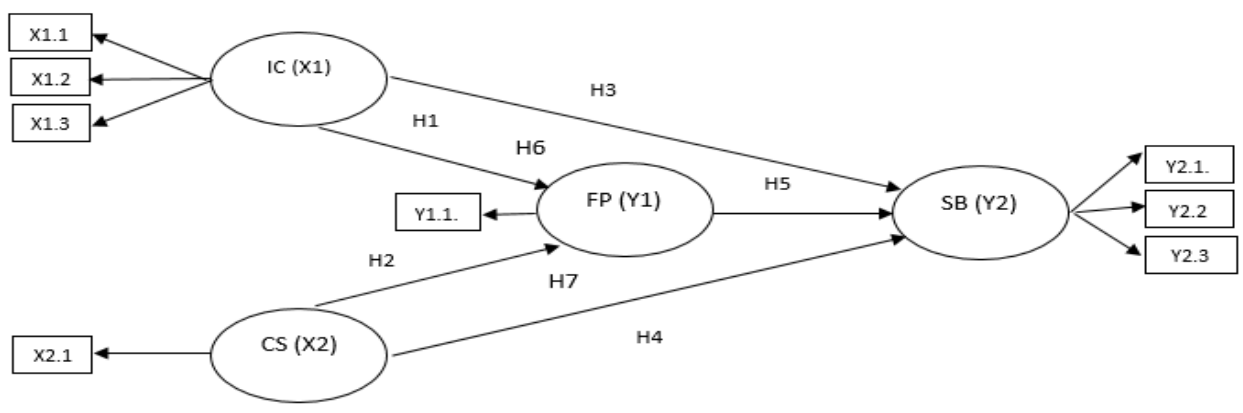

Figure 1. Research Framework

\section{Hypothesis}

Based on the background and results of research previously, it is found that there is a research gap from the results of research previously. This, as stated by Dzemyda and

Vol. 27, No. 2 August 2019 
Jurgelevicius (2014) states that intangible assets consisting of intellectual capital, human capital and social capital were able to change the economic structure of a country and affected the sustainability of a country's development. Akhtar et al. (2015) stated that intellectual capital has a significant effect on SME's sustainable business. This is different from the results of the research by Juwita and Anggraini (2007) stated that intellectual capital has no effect sustainable business performance.

Furthermore, from the background, there is a research gap from the results of research previously about the influence of company size on sustainable business. The results of Hackston and Milne (1996); Wahyuningsih and Mahdar (2018) state that company size has a significant effect on sustainable business. While the results of Swandari and Sadikin (2016) state that company size has no effect on sustainable business. According to research gap above, the researcher suggested the following hypothesis:

\section{Intellectual Capital On Financial Performance}

From the results of previous research, Bontis et al. (2000) stated that structural capital (SC) has a significant effect on business performance. Firer and Williams (2003) state that there is a significant effect, intellectual capital on company performance as measured by profitability, productivity and market valuation. Chen et al. (2005) stated that intellectual capital has a significant effect on financial performance. Ulum et al. (2008) states that intellectual capital has a significant effect on financial performance. Carrington (2012); Fathi et al. (2013); Nawaz et al. (2014); also stated that intellectual capital has a significant effect on financial performance.

Based on he above previous research findings it can be explained that intellectual capital has a very major influence for the company because basically, intellectual capital is a resource that has the potential to determine the company's competitive advantage. This also means that intellectual capital is a factor of resources and knowledge that supports the running of the company. Companies that have high intellectual capital values indicate that the company can combine the existence of resources owned, ranging from human capital (HC), structural capital (SC) to capital employed (CE). With proper intellectual capital management, financial performance will also increase. Based on the discussions, the hypothesis can be proposed as follows:

H1: Intellectual capital has a significant effect on financial performance 


\section{The Company size On Financial Performance}

The Company size is a scale which can be classified as the company standard according to various methods, including the total assets. The company size will effect the ability to bear the risks that may arise from various situations faced by the company. Company size also determines the level of investor confidence. The bigger company, the better it is known by the community, which means it is easier to get information that will increase the value of the company. In fact, big company that have total assets with a large enough asset value can attract investors to invest in the company (Prasetyorini, 2013). Thus companies with a big size have access to sources of funding from various sources, so that getting a loan from a creditor will be easier. In most cases it is because the companies with the big measure have high profit.

Firmansyah and Suwitho (2017) states that company size as measured by total assets has a significant effect on financial performance of manufacturing companies listed on the Indonesia Stock Exchange. Likewise, the result of Mwangi (2018) states that company size has a significant effect on financial performance of Commercial Banks in Kenya. Based on the description, the hypothesis can be proposed as follows:

$\mathrm{H} 2$ : company size has a significant effect on financial performance

\section{Intellectual Capital On Sustainable Business}

As the results of research previously, Dzemyda and Jurgelevicius (2014) stated that intangible assets consist of intellectual capital, human capital and social capital were able to change the economic structure of a country and influence the sustainability of a country's development. Akhtar et al. (2015) stated that intellectual capital has a significant effect on SME's sustainable business.

From the results of research previously it can be explained, companies that have intellectual capital if managed properly can encourage companies to work more effectively and efficiently so as to create a competitive advantage in the business world, encourage improvement in financial performance so that it can form a sustainable business. Based on the description, the following hypotheses can be proposed:

H3: Intellectual capital has significant effects on sustainable business

Vol. 27, No. 2 August 2019 


\section{Company size On Sustainable Business}

Consideration of investment decision making, investors often see the company size and evaluate financial performance. The company size is an estimate variable that is widely used to explain variations in social disclosures in annual reports made by companies. This is related to agency theory that predicts large companies that have higher agency costs will reveal more information in order to reduce the high agency costs (Sembiring, 2006). Larger companies tend to have higher information public demand than smaller companies (Sembiring, 2006). Research of Hackston and Milne (1996) shows that the company size has a significant effect on sustainable business. Based on the description, the following hypotheses can be proposed:

H4: Companya size has significant effects on sustainable business

\section{Financial Performance On Sustainable Business}

Research Nawaiseh (2015) state that financial performance reflected in return on asset (ROA) has a significant effect on sustainable business. Maskun (2013) stated that leverage, company size and profitability have a significant effect on CSR disclosure, which in turn can improve people's welfare. Sari and Marsono (2013) stated that profitability has a significant effect on disclosure of sustainability report.

From the results of research previously it can be explained that companies that have a good level of financial performance tend to increase investment by opening up lines and branches of business. Thus if a company has good financial performance value, the company will be sustainable. Therefore it can be said that the financial performance of a good company will be able to improve the ability of the company in increasing social responsibility, which in turn will be able to improve people's welfare. Based on the description, the following hypotheses can be proposed:

H5: Financial performance has significant effects on sustainable business

\section{Financial Performance Mediates Effect of Intellectual Capital on Sustainable Business}

Research Dzemyda and Jurgelevicius (2014) stated that intangible assets consist of intellectual capital, human capital and social capital were able to change the economic 
structure of a country and influence the sustainability of a country and Akhtar et al. (2015) that intellectual capital has a significant effect on SME's sustainable business. Akhtar et al. (2015) stated that intellectual capital has a significant effect on SME's sustainable business. This is different from the results of research by Juwita and Anggraini (2007) stated that intellectual capital does not affect sustainable business performance.

Based on the research gap, the researcher wants to examine the effect of intellectual capital on sustainable business through financial performance as a mediating variable. From this description, the following hypotheses can be proposed:

H6: Financial performance mediates the effect of intellectual capital on sustainable business

\section{Financial Performance Mediates Effect of Company size on Sustainable Business}

As the results of research previously, Hackston and Milne (1996), Wahyuningsih and Mahdar (2018) state that company size has a significant effect on sustainable business. Based on the research gap, the researcher wants to examine the effect of company size on sustainable business through financial performance as a mediating variable. From this description, the following hypotheses can be proposed:

H7: Financial performance mediates the effect of company size on sustainable business

\section{METHODOLOGY}

The types of data in this research are secondary data in the form of annual reports and financial reports of all Islamic banks used as samples in this study, data from 2010 - 2018. The reasons for using Islamic banks as objects in this study are because market share Islamic banks in Indonesia are relatively small compared with conventional commercial banks. This research is intended to see the performance improvement of Islamic banks by analise intellectual capital, company size, financial performance and business sustainability. The reason for using the 2010 - 2018 period chosen in this study was that during 2010 - 2018, there were significant developments in the context of increasing the total assets of Islamic banks in Indonesia.

Vol. 27, No. 2 August 2019 
The variables used in this research are as follows: Intellectual capital as an independent variable (X1), company size as an independent variable (X2), financial performance as an intervening variable (Y1), and sustainable business as a dependent variable (Y2). The population determination criteria in this study are as follows:

1. Islamic banks that issue financial statements in period $2010-2018$

2. Islamic banks that issue annual reports in period 2010 - 2018

From above criteria, the Islamic banks that can enter the population of this research are 9 (nine) Islamic banks. The sample in this research was taken by the saturated sampling method that is by using all Islamic banks which become populations, there are 9 (nine) Islamic banks. The sample used in this research are: 1. Bank Muamalat; 2. Bank Mandiri Syariah; 3. Bank Mega Syariah; 4. Bank BRI Syariah; 5. Bank BNI Syariah; 6. Bank Bukopin Syariah; 7. Bank BCA Syariah; 8. Bank Panin Syariah; 9. Bank Victoria Syariah.

Based on the relationship of variables used in research and problem formulation, this research uses partial least square (PLS) to data analysis techniques. The reason for using partial least square (PLS) because PLS is more predictive model and is a powerful analytical method because it is not based on many assumptions (Ghozali, 2014). For example, data must be normally distributed, samples do not have to be large. Besides being used to confirm the theory, PLS can also be used to explain whether there is a relationship between latent variables. PLS can simultaneously analyze the constructs formed with reflective and formative indicators.

The limitations in this research are not to distinguish the status of the Islamic banks used in this study whether the Islamic banks have status as foreign exchange banks or non-foreign exchange banks.

\section{RESULT AND DISCUSSION}

\section{Test Validity and Reliability}

Validity and reliability tests for all variables in this research can be seen from the results of convergent validity, discriminant validity and composite reliability, as shown in table 1 below. 
Table 1

Test Validity

\begin{tabular}{|c|c|c|c|c|}
\hline & & & financial & \\
\hline & intellectual capital & company size & performance & sustainable business \\
\hline $\mathrm{X} 1.1$ & 0,813 & & & \\
\hline $\mathrm{X} 1.2$ & 0,866 & & & \\
\hline $\mathrm{X} 1.3$ & 0,873 & & & \\
\hline $\mathrm{X} 2$ & & 1,000 & & \\
\hline Y1 & & & 1,000 & \\
\hline Y2.1 & & & & 0,982 \\
\hline $\mathrm{Y} 2.2$ & & & & 0,950 \\
\hline $\mathrm{Y} 2.3$ & & & & 0,959 \\
\hline
\end{tabular}

(Data processed 2019)

Based on the Table 1, it can be explained that the results of convergent validity tests of intellectual capital variable consisting of 3 indicators, are: human capital, structural capital and employer capital indicate that the variable outer loading indicator has a value $>0.50$. Thus, overall it can be stated that measurement indicators for intellectual capital variable has met the convergent validity test. From Table 1 it can be seen that the loading factor value of each indicator has a value of above 0.50 , it shows that all indicators ( 3 indicators) are stated to significantly measure the variable of intellectual capital.

Based on the Table 1, it can be explained that the result of covergent validity test of Company Size variable show that the outer loading variable Companya Size has a value $>0.50$. Thus it can be stated that measurement of Company Size variable has met the covergent validity test.

Based on the Table 1, it can be explain that the results of convergent validity test of Financial Performance variables show that the outer loading of financial performance variables has a value $>0.50$. Thus it can be stated that the measurement of the Financial Performance variable has met the covergent validity test.

Based on the Table 1 the test results obtained for the convergent validity of sustainable business variable consist of 3 indicators, are: economic performance, social performance and environmental performance indicate that the outer loading variable of sustainable 
business indicator has a value $>0.50$. Thus, overall it can be stated that the measurement of indicators for the sustainable business variable has met the convergent validity test. From Table 1 it can be seen that the loading factor value of each indicators have a value $>0.50$, it shows that all indicators ( 3 indicators) are stated to significant measure sustainble business variable.

Table 2

AVE Test, Reliability and Cronbach Alpha

\begin{tabular}{lccc}
\hline & AVE & Composite Reliability & Cronbach Alpha \\
\hline X1 & 0,724 & 0,887 & 0,816 \\
X2 & 1,000 & 1,000 & 1,000 \\
Y1 & 1,000 & 1,000 & 1,000 \\
Y2 & 0,929 & 0,975 & 0,962 \\
\hline
\end{tabular}

(Data processed 2019)

Based on the Table 2, the results of composite reliability of intellectual capital show a value of 0.887 , this value indicates that the intellectual capital variable has a reliability value $>0.50$. The results of the disriminant validity test can be seen from the root value of average variance extracted (AVE) which has a higher value than the value of the correlation between other constructs, it shows that each variable has high disriminant validity. The Cronbach Alpha value for each variable has a value more 0.70. This shows that all variables have very strong reliability values.

Based on the Table 2, the results of composite reliability of company size show a value of 1,000 , this value indicates that the company size variable has a reliability value $>0.50$. The results of the disriminant validity test can be seen from the root value of average variance extracted (AVE) which has a higher value than the value of the correlation between other constructs, it shows that each variable has high disriminant validity. The Cronbach Alpha value for each variable has a value more 0.70. This shows that all variables have very strong reliability values.

Based on the Table 2, the results of composite reliability of financial performance show a value of 1,000 . This value indicates that the financial performance variable has a reliability value $>0.50$. The results of the disriminant validity test can be seen from the root value of average variance extracted (AVE) which has a higher value than the value 
of the correlation between other constructs, it shows that each variable has high disriminant validity. The Cronbach Alpha value for each variable has a value more 0.70 . This shows that all variables have very strong reliability values.

Based on the Table 2, the results of composite reliability sustainable business show a value of 0,975 , this value indicates that the sustainable business variable has a reliability value $>0.50$. The results of the disriminant validity test can be seen from the root value of average variance extracted (AVE) which has a higher value than the value of the correlation between other constructs, it shows that each variable has high disriminant validity. The Cronbach Alpha value for each variable has a value more 0.70 . This shows that all variables have very strong reliability values.

Based on the table 2, it can be explained that the results of the composite reliability test of intellectual capital variables, company size, financial performance and sustainable business show a value of $>0.50$. Thus, overall it can be concluded that the measurement indicators for each variable have met the comosite reliability test. The results of the disriminant validity test can be seen from the root value of average variance extracted (AVE) which has a higher value than the value of the correlation between other constructs, it shows that each variable has high disriminant validity. The Cronbach Alpha value for each variable has a value more 0.70 . This shows that all variables have very strong reliability values.

\section{Partial Least Square Analysis}

The study uses Smart PLS 3.0 partial least square analysis (PLS). Below is the PLS model as shown in Figure 2 below. 
Figure 2

\section{Hypothesis Testing Results}

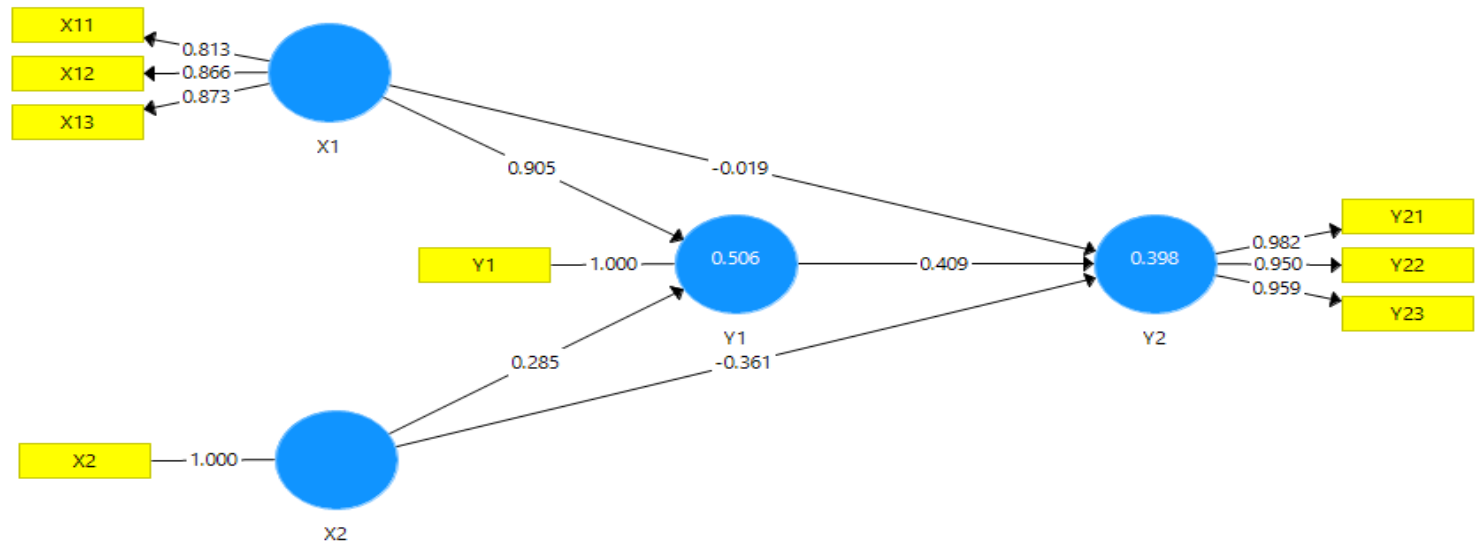

(Data processed 2019)

Based on data processed with PLS, R-Square values can be obtained as shown in the table 3 below.

\section{Table 3}

\section{Value of R-Square}

\begin{tabular}{lr}
\hline Variable & R-Squar \\
\hline Intellectual capital (X1) & \\
Company size (X2) & \\
Financial performance (Y1) & 0.506 \\
Sustainable business (Y2) & 0.398
\end{tabular}

(Data processed 2019)

Based on the results of calculations in the table 3, to test the feasibility of the model is done using predictive-relevance $(\mathrm{Q} 2) \mathrm{Q}$-square value. The formula and results of Qsquare calculations are as follows:

$$
\begin{aligned}
& \mathrm{Q}^{2}=1-\left(1-\mathrm{R}_{1}^{2}\right)\left(1-\mathrm{R}_{2}^{2}\right) \\
& \mathrm{Q}^{2}=1-(1-0.506)(1-0.398)=0.7026=70.26 \%
\end{aligned}
$$

The calculation results show predictive-relevance (Q2) Q-square value of 70.26\%. The predictive-relevance (Q2) Q-square value of $70.26 \%$ indicates that the 
model built is good because it has a predictive relevance of $70.26 \%$. Thus the model that has been built is feasible to be used to test the hypothesis.

Table 4

Recapitulation of Research Results

\begin{tabular}{|c|c|c|c|c|c|}
\hline $\begin{array}{l}\text { Hypothes } \\
\text { is }\end{array}$ & $\begin{array}{c}\text { Influence between } \\
\text { variables }\end{array}$ & $\begin{array}{c}\text { Path } \\
\text { coefficien } \\
\mathbf{t}\end{array}$ & $\begin{array}{c}\text { P- } \\
\text { Value }\end{array}$ & $\begin{array}{c}\text { Sobel } \\
\text { test }\end{array}$ & Information \\
\hline & Direct influence & & & & \\
\hline H1 & $\begin{array}{c}\text { intellectual capital -> } \\
\text { Financial } \\
\text { performance }\end{array}$ & 0.905 & 0.0000 & & significant \\
\hline H2 & $\begin{array}{c}\text { company size -> } \\
\text { financial performance }\end{array}$ & 0.285 & 0.0410 & & significant \\
\hline $\mathbf{H 3}$ & $\begin{array}{l}\text { intellectual capital -> } \\
\text { sustainable business }\end{array}$ & - 0.019 & 0.9040 & & $\begin{array}{c}\text { no } \\
\text { significant }\end{array}$ \\
\hline H4 & $\begin{array}{l}\text { company size -> } \\
\text { sustainable business }\end{array}$ & -0.361 & 0.0040 & & significant \\
\hline H5 & $\begin{array}{c}\text { financial performance } \\
\text {-> } \text { sustainable } \\
\text { business }\end{array}$ & 0.409 & 0.0040 & & significant \\
\hline & Indirect Effects & & & & \\
\hline \multirow{2}{*}{ H6 } & $\begin{array}{c}\text { intellectual capital -> } \\
\text { Financial } \\
\text { performance }\end{array}$ & 0.905 & 0.0000 & 3.786 & full mediate \\
\hline & $\begin{array}{c}\text { financial performance } \\
\text {-> } \text { sustainable } \\
\text { business }\end{array}$ & 0.409 & 0.0040 & & \\
\hline \multirow[t]{2}{*}{ H7 } & $\begin{array}{c}\text { company size -> } \\
\text { financial performance }\end{array}$ & 0.285 & 0.0410 & 2.084 & $\begin{array}{c}\text { partial } \\
\text { mediate }\end{array}$ \\
\hline & $\begin{array}{c}\text { financial performance } \\
\text {-> sustainable }\end{array}$ & 0.409 & 0.0040 & & \\
\hline
\end{tabular}

Vol. 27, No. 2 August 2019

(C) Centre for Indonesian Accounting and Management Research Postgraduate Program, Brawijaya University 
\begin{tabular}{|l|l|l|l|l|l|}
\hline & business & & & & \\
\hline
\end{tabular}

(Data processed 2019)

From the table 4, the results of the hypothesis test can be explained that the Pvalue value of the influence of intellectual capital on financial performance shows the number $0.000<0.05$, thus it can be said that intellectual capital has a significant effect on financial performance. The results of these studies are in line with the results of research conducted by Bontis et al. (2000); Firer and Williams (2003); Chen et al. (2005); Ulum et al. (2008); Carrington (2012); Fathi et al. (2013) and Nawaz et al. (2014) stated that intellectual capital has a significant effect on financial performance. Thus it can be concluded that good intellectual capital is able to improve financial performance, so that the hypothesis proposed in this study can be accepted and supported by empirical facts. This indicates that the better the intellectual capital can directly influence financial performance. Based on the description and results of the study, it can be said that the hypothesis proposed in this study is accepted.

From the results of the hypothesis test it can be explained that the P-value value of the influence of company size on financial performance shows the number 0.0410 $<0.05$, thus it can be said that the company size has a significant effect on financial performance. Thus it can be stated that the size of the company shows the amount of assets in a company and an increase in the size of the company can increase the company's profit. The results of the study are in line with the results of research conducted by: Firmansyah and Suwitho (2017) and Mwangi (2018) which state that company size has a significant effect on financial performance. Based on the description and results of the study, it can be said that the hypothesis proposed in this research is accept.

From the results of the hypothesis test it can be explained that the P-value value of the influence of intellectual capital on sustainable business shows the number 0.9040> 0.05 , thus it can be said that intellectual capital does not affect sustainable business. Thus it can be concluded that good intellectual capital can improve sustainable business, so the hypothesis proposed in this study can be accepted and supported by empirical facts. This indicates that intellectual capital has an effect on sustainable business. The results of the study are in line with the results of research conducted by Juwita and Anggraini (2007) 
stating that intellectual capital does not affect sustainable business performance, but the results of these studies are not in line with the results of research by Dzemyda and Jurgelevicius (2014) and Akhtar et al. (2015) stated that intellectual capital has a significant effect on sustainable business. Based on the description and results of the study, it can be said that the hypothesis proposed in this study is not accept.

From the results of the hypothesis test it can be explained that the P-value value of the influence of company size on sustainable business shows a figure of $0.0040<0.05$, thus it can be said that the company size has a significant effect on sustainable business. The results of the study are in line with the results of research conducted by Hackston and Milne (1996) state its results that company size has a significant effect on sustainable business. Based on the description and results of the research, it can be said that the hypothesis proposed in this research is accept.

The results of the study from the results of the hypothesis test it can be explained that the value of $\mathrm{P}$-value influences financial performance on sustainable business shows the number $0.0040<0.05$, thus it can be said that financial performance has a significant effect on sustainable business. Thus it can be concluded that good financial performance can improve sustainable business, so the hypothesis proposed in this study can be accepted and supported by empirical facts. This indicates that financial performance has an effect on sustainable business. The results of the study are in line with the results of research conducted by Nawaiseh (2015); Sari and Marsono (2013) which state that profitability (ROA) has a significant effect on sustainable business. Based on the description and results of the study, it can be said that the hypothesis proposed in this research is accept.

Based on the results of direct and indirect effect of intellectual capital on sustainable business through financial performance and based on the Sobel test it is identified that the coefficient value of indirect effect of intellectual capital on sustainable business through financial performance shows $3,786>1.96$. Thus it can be concluded that financial performance is able to mediate the influence of intellectual capital on sustainable business on Islamic banks, so that the hypothesis proposed in this study can be accepted and supported by empirical facts. This shows that good financial performance can mediate the influence of intellectual capital on sustainable business of Islamic banks. Thus it can

Vol. 27, No. 2 August 2019 
be said that financial performance fully mediates effect of intellectual capital on sustainable business.

Based on the results of the direct and indirect effects of company size on sustainable business through financial performance and based on the Sobel test it is identified that the coefficient value of indirect effect company size on sustainable business through financial performance shows $2.084>1.96$. Thus it can be said that financial performance partially mediates the effect of company size on sustainable business.

\section{CONCLUSIONS AND SUGGESTIONS}

From the results of the study, it can be concluded that the sustainable business of Islamic banks is influenced by financial factors and non-financial factors. As empirically found, intellectual capital has a significant effect on financial performance. Company size has a significant effect on financial performance, where as intellectual capital has no effect on sustainable business. The study also finds that financial performance has a significant effect on sustainable business. Financial performance has a full mediating influence of intellectual capital on sustainable business, and financial performance has a partial mediating influence of company size on sustainable business.

\section{LIMITATIONS AND SUGGESTIONS FOR FUTURE RESEARCH}

The limitations of this study are not differentiating status of group banks in foreign exchange banks or non-foreign exchange banks. It is recommended for future research to replicate the results of this study by using different research objects, such as other Islamic financial institutions, Islamic insurance companies, and Baitul Maal wa Tamwil (BMT) institutions. 


\section{REFERENCES}

Akhtar, C.S., Ismail, K., Ndaliman, M.A., Hussain, J., and Haider, M. 2015. Can Intellectual Capital of SMEs Help in Their Sustainability Efforts. Journal of Management Research 7(2): 83 - 97.

Alex, Muhindi Kibet and Ngaba, Domnic. 2018. Effect Of Firm Size On Financial Performance On Banks:Case of Commercial Banks In Kenya. International Academic Journal of Economics and Finance 3(1): 175-190.

Asmirantho, Edhi. 2013. Financial Management. Learning Books, Pakuan University

Bary dan Bouma (2009). Mengapa Bisnis Perlu Menerapkan Sustainability. (Why business need to Implementation Sustainability) (www.pa-internastional.org), diakses (accessed) 21 Maret 2019.

Bollen, L., Philip V., and Stephanie S. 2005. Linking Intellectual Capital and Intellectual Property to Company Performance. Journal Management Decision 43(9):11611185.

Bontis, N., Keow, W.C.C., and Richardson, S. 2000. Intellectual capital and business perfor-mance in Malaysian industries. Journal of Intellectual Capital 1(1):85-100.

Carrington, Donley. 2013. Intellectual Capital and Its Influence on the Financial Performance of Companies in Under Developed Capital Markets - the Case of the Caribbean. The Proceedings of The 10 th International Conference On Intellectual Capital, Knowledge Management \& Organisational Learning ICICKM-2013. The George Washington University Washington DC, USA 24-25 October.

Chen,Ming.C., Cheng, Shu.J, and dan Hwang, Yuh.C. 2005. An empirical investigation of the relationship between intellectual capital and firms' market value and financial performance. Journal of Intellectual Capital 6(2):159-176.

Dilling, Petra.F.A. 2009. Sustainability Reporting In A Global Context : What Are The Characteristics of Corporations That Provide High Quality Sustainability Reports An Empirical Analysis. International Business \& Economics Research Journal .9(1):19-30.

Dzemyda, Ignas and urgelevicius, Arturas. 2014. The Impact of Intangible Capital Countries' Sustainability During The Economical Recession. 8th International

Vol. 27, No. 2 August 2019 
Scientific Conference “Business and Management 2014” May 15-16. :814-822, Vilnius, Lithuania.

Elkington, John. 1998. Cannibals with Forks: The Triple Bottom Line of 21st Century Business, Gabriola Island, New Society Publishers.

Fathi, S., Farahmand, S., and Khorasani, M. 2013. Impact of Intellectual Capital on Financial Performance. International Journal of Acaemic Science 2(1):6-17.

Firer dan Williams. 2003. "Intellectual Capital dan Traditional Measures of corporate Performance". Journal of Intellectual Capital. 4(3):348-360.

Firmansah, Arif dan Suwitho. 2017. Pengaruh ukuran perusahaan dan profitabilitas terhadap nilai perusahaan melalui kebijakan deviden. (Effect of company size and profitability on company value through dividend policy), Jurnal Ilmu dan Riset Manajemen 6(1): 1-18

Ghozali, Imam. 2014. Structural Equation Modeling, Metode Alternatif dengan Partial Least Square (PLS). (Structural Equation Modeling, Alternative Methods with Partial Least Square) Edisi 4. Semarang : Badan Penerbit Universitas Diponegoro. GRI, 2013, Global Reporting Initiative G4, http://www.Globalreporting.org. Accessed on February 2019.

Hackston, D., dan M.J. Milne. 1996. Some determinants of social and environmental disclosures in New Zealand companies. Accounting, Auditing and Accountability Journal, Vol. 9, No. 1, hal 77-108.

Ikatan Akuntan Indonesia, 2007.Standar Akuntasi Keuangan. (financial accounting standards) Jakarta: Salemba Empat.

Juwita, Siti Pritiza dan Fivi Anggraini. 2007. Pengaruh Human Capital Terhadap Business Performance Melalui Customer Capital (Studi Empiris Pada Perusahaan komoditi Ekspor di Sumatera Barat). (Effects of Human Capital on Business Performance Through Customer Capital (Empirical Study on Export Commodity Companies in West Sumatra). The $1^{\text {st }}$ Accounting Conference Faculty of Economics Universitas Indonesia.

Maskun, Ali. 2013. Leverage level, company size, profitability toward the disclosure of Corporate Social Responsibility (CSR) of Lq-45 companies in Indonesia stock xchange. International Journal of Academic Research. 5(2):140-144. 
Mwangi, Mirie. 2018. The Effect of Size on Financial Performance of Commercial Banks in Kenya. European Scientific Journal. 14(7):373.-385

Nawaiseh, Mohammad. 2015. Do Company size and Financial Performance Affect Corporate Social Responsibility Disclosure: Employees' and Environmental Dimensions? American Journal of Applied Sciences 12(12):967-981.

Nawaz, T., Haniffa, R., and Hudaib, M. 2014. The Impact of Intellectual Capital on Corporate Performance of Islamic Financial Institutions. Proceedings of the International Conference on Intellectual Capital:519.

Prasetyorini, Bhekti Fitri 2013. Pengaruh Ukuran Perusahaan, Leverage, Price Earning Ratio Dan Profitabilitas Terhadap Nilai Perusahaan. (Effect of Company Size, Leverage, Price Earning Ratio and Profitability on Company Values ). Jurnal Ilmu Manajemen. 1(1):183-196

Rezaei, Emad. 2014. Statistical Analysis of The Impact of Intellectual Capital elements on Future Performance: A Case Study of Tehran Stock Exchange. Research Journal of Recent Sciences 3(12):131-137.

Sari, Mega Putri., and Marsono. 2013. Pengaruh Kinerja Keuangan, Ukuran Perusahaan dan Corporate Governance Terhadap Pengungkapan Sustainability Report. (Effect of Financial Performance, Company Size and Corporate Governance on Sustainability Report Disclosures). Diponegoro Journal Of Accounting 2(3):1-10.

Sembiring, Edi Rismanda. 2005. Karakteristik Perusahaan dan Pengungkapan Tanggung Jawab Sosial: Studi Empiris pada Perusahaan yang Terdaftar di BEI. (Corporate Characteristics and Disclosure of Social Responsibility: Empirical Study of Companies Listed on the BEI). Simposium Nasional Akuntansi VIII .

Siswanti, Indra., Salim, Ubud., Sukoharsono, Eko Ganis dan Asijah, Siti. 2017. The Impact of Islamic Corporate Governance, Islamic Intellectual Capital and Islamic Financial Performance on Sustainable Business Islamic Banks. International Journal of Economics and Financial Issues (IJEFI), 2017, 7(4): 316-323

Swandari, Fifi dan Sadikin, Ali. 2016. The Effect of Ownership Structure, Profitability, Leverage, and Firm Size on Corporate Social Responsibility (CSR). Binus Business Review, 7(3). 315 - 320.

Vol. 27, No. 2 August 2019 
Ulum, Ihyaul., Ghozali, Imam., and Chariri, Anis. 2008. Intellectual Capital dan Kinerja Keuangan Perusahaan: Suatau Analisis Dengan Pendekatan Partial Least Squares. (Intellectual Capital and Corporate Financial Performance: An Analysis with a Partial Least Squares Approach). Simposium Nasional Akuntansi 11 (SNA 11), (National Accounting Symposium 11), 23 - 24 Juli 2008, Universitas Tanjung Pura Pontianak.

Wahyuningsih, Ana \& N. M. Mahdar. 2018. Pengaruh Size, Leverage, dan Profitabilitas Terhadap Pengungkapan CSR pada Perusahaan Manufaktur yang terdaftar di BEI.( Effect of Size, Leverage, and Profitability on CSR Disclosures on Manufacturing Companies listed on the BEI) Jurnal Bisnis dan Komunikasi, 5(1):27-36 
The International Journal of Accounting and Business Society

Vol. 27, No. 2 August 2019

(C) Centre for Indonesian Accounting and Management Research Postgraduate Program, Brawijaya University 